\title{
Results from Scotland's 2018 Report Card on Physical Activity for Children and Youth
}

\author{
Adrienne R. Hughes, Avril Johnstone, Farid Bardid, and John J. Reilly
}

\section{Introduction}

Previous Active Healthy Kids Scotland Report Cards from 2013 and 2016 (www.activehealthykidsscotland.co.uk) demonstrated that only a small minority of Scottish school-aged children and adolescents meet the recommended amount of daily moderate-tovigorous intensity physical activity (MVPA; $\geq 60$ minutes). ${ }^{1,2}$ These low levels of MVPA occur despite a favorable physical and policy environment in Scotland., ${ }^{1,2}$ Previous report cards also identified major limitations in surveillance of physical activity and related behaviors in Scotland. The aim of this short paper is to (a) summarize the Scottish grades included in the Global Matrix 3.0 (www.activehealthykids.org) and (b) highlight the continuing limitations in surveillance of physical activity among children and adolescents in Scotland.

\section{Methods}

Similar to previous report cards in Scotland, data sources were used for grading if they had been derived from recent (i.e. from 2014 onwards) nationally representative surveys, and if methods of measurement had small or negligible bias. ${ }^{1,2}$ The main data sources used for the Scottish grades for the Global Matrix 3.0 were the Health Behaviours in School-Age Children survey (HBSC) 2014, the Scottish Health Survey (SHeS) 2016, Hands Up Scotland (HUS) 2016, Transport \& Travel in Scotland (TATIS) 2016 and the Scottish Household Survey (SHS) 2016. The report card working group graded the 10 core physical activity indicators included in the Global Matrix 3.0 (Overall Physical Activity, Organized Sport and Physical Activity, Active Play, Active Transportation, Sedentary Behaviors, Family and Peers, School, Community and Environment, Government, and Physical Fitness). The grades were reviewed by key stakeholders from national organizations before being finalized and submitted to the Global Matrix 3.0. The grades for the 2018 Active Healthy Kids Scotland Report Card (to be released later in 2018) may differ in some respects from the Scottish grades included in the Global Matrix 3.0, as the Scottish report card will include evidence for children under 5 years old and additional indicators (obesity and diet).

\section{Results and Discussion}

Scottish grades for the Global Matrix 3.0 are summarized in Table 1. Scotland's 2018 Report Card cover is displayed in Figure 1. Four indicators (including Active Play and Physical
Fitness) could not be graded due to a lack of appropriate data, which highlights continuing major gaps in the surveillance of important health behaviors and influences in Scotland. Furthermore, two grades (Overall Physical Activity and Sedentary Behaviours) were based on limited data from the previous (2016) report card. For instance, the Overall Physical Activity grade was based on adolescent data from the 2014 Health Behaviour in School-aged Children survey; our main Scottish national survey, the Scottish Health Survey ${ }^{5}$ could not be used for grading because it assumes that all child and adolescent physical activity reported by parents is MVPA, resulting in a substantial overestimation of MVPA levels. ${ }^{1,2,6}$

The WHO has recently emphasised the importance of child physical activity and sedentary behaviour surveillance and policy for obesity and NCDs prevention and control. ${ }^{7}$ Weaknesses in Scottish surveillance, policy, and evaluation suggest that important opportunities for obesity and NCD prevention and control are being missed.

\section{Conclusion}

Few Scottish children and adolescents meet the guidelines for physical activity and sedentary behaviour. These problems begin well before adolescence, affect both $\operatorname{sexes}^{8,9}$ and exist despite a favorable policy and physical environment, ${ }^{1,2}$ suggesting that cultural barriers to physical activity and drivers of sedentary behavior may be important. Several indicators could not be graded,

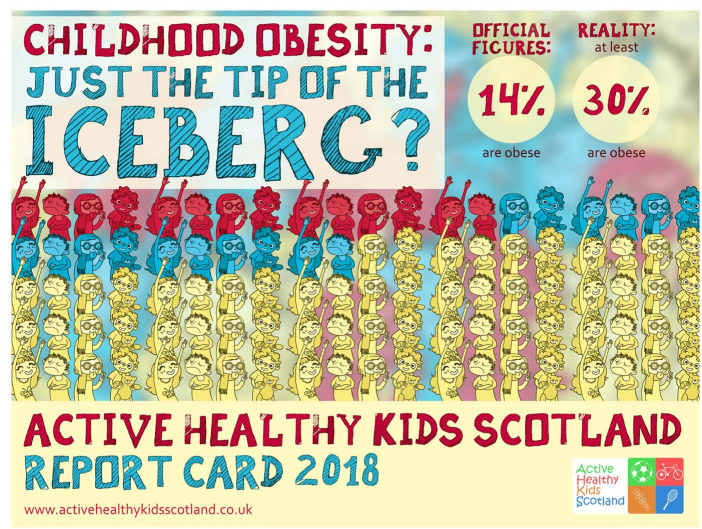

Figure 1 - Scotland's 2018 Report Card cover.

Hughes, Johnstone, and Reilly are with the Physical Activity for Health Group, School of Psychological Sciences and Health, University of Strathclyde, Glasgow, UK. Bardid is with the School of Education, University of Strathclyde, Glasgow, UK; and the Department of Movement and Sports Sciences, Ghent University, Ghent, Belgium. Hughes (adrienne.hughes@strath.ac.uk) is corresponding author. 


\section{Table 1 Grades and rationales for Scotland's 2018 Report Card}

\begin{tabular}{|c|c|c|}
\hline Indicator & Grade & Rationale \\
\hline Overall Physical Activity & $\mathrm{F}$ & $\begin{array}{l}\text { This grade has been carried forward from the } 2016 \text { Scottish report card }{ }^{2} \text { because no data source since the } \\
\text { previous card measured this indicator according to the Global Matrix } 3.0 \text { benchmark. The data source (HBSC } \\
2014)^{3} \text { reported that } 18 \% \text { of } 11 \text { to } 15 \text { year olds achieved } \geq 60 \text { mins of MVPA/day on all } 7 \text { days One recent data } \\
\text { source found that } 11 \% \text { of } 10 \text { to } 11 \text { year olds achieved } \geq 60 \text { mins of MVPA/day on each day of wear using } \\
\text { Actigraph, supporting the F grade. }\end{array}$ \\
\hline $\begin{array}{l}\text { Organized Sport \& Physi- } \\
\text { cal Activity }\end{array}$ & $\mathrm{B}$ & $73 \%$ of $5-15$ year olds reported as participating in organised sport and physical activity in the past week. ${ }^{5}$ \\
\hline Active Play & INC & $\begin{array}{l}\text { No data source measured or reported this indicator according to the Global Matrix } 3.0 \text { benchmark, so this } \\
\text { indicator could not be graded, as in previous Scottish cards. } 1,2\end{array}$ \\
\hline Active Transportation & $\mathrm{C}$ & $\begin{array}{l}\text { Scottish data are available only for active commuting to/from school, from two nationally representative surveys } \\
\text { (HUS 2016; TATiS 2016) which suggested that 51-52\% of school age children and adolescents in Scotland } \\
\text { actively commuted to school. }\end{array}$ \\
\hline Sedentary Behaviours & $\mathrm{F}$ & $\begin{array}{l}\text { This grade has been carried forward from the } 2016 \text { Scottish report card }{ }^{2} \text { because no data source since the } \\
\text { previous card has reported this indicator according to the Global Matrix } 3.0 \text { benchmark. HBSC } 2014^{3} \text { found that } \\
64 \% \text { (weekdays) and } 79 \% \text { (weekend days) of } 11-15 \text { year olds reported spending }>2 \mathrm{hrs} / \mathrm{d} \text { in TV viewing alone. } \\
\text { On weekdays, } 65 \% \text { of boys ( } 78 \% \text { weekend) and } 46 \% \text { of girls ( } 57 \% \text { weekend) played screen-based electronic } \\
\text { games for }>2 \mathrm{hrs} / \mathrm{day} \text {, and } 66 \% \text { of girls ( } 74 \% \text { weekend) and } 60 \% \text { of boys }(68 \% \text { weekend) used computers for } \\
\text { purposes other than games for }>2 \mathrm{hrs} / \mathrm{d} \text {. Combining the proportion of young people exceeding } 2 \mathrm{hrs} / \text { day for each } \\
\text { form of screen time (i.e. TV viewing, gaming and other computer use) justifies the F grade. }\end{array}$ \\
\hline Family and Peers & INC & No Scottish data sources fitted the Global Matrix 3.0 benchmark for this indicator. \\
\hline School & INC & No eligible Scottish data sources available. \\
\hline $\begin{array}{l}\text { Community and } \\
\text { Environment }\end{array}$ & B- & $\begin{array}{l}\text { The SHS } 2016 \text { reported that } 92 \% \text { of households with children aged 6-12 years had access to at least one play area } \\
\text { within their neighbourhood. } 66 \% \text { of households with children aged 6-12 years felt that it was safe for children to } \\
\text { go to a playground in their neighbourhood with } 2 \text { or } 3 \text { friends ( } 61 \% \text { to a park, } 62 \% \text { to field/other open space, } 57 \% \\
\text { for streets around the home); } 59 \% \text { of households felt that it was safe for children to walk/cycle on their own to a } \\
\text { playground in their neighborhood ( } 55 \% \text { to a park, } 57 \% \text { to a field/other open space, } 56 \% \text { for streets around the } \\
\text { home). This indicator was graded as B-, although access is high (A grade), safety is lower and varies by play area } \\
\text { and whether child is alone (C+ grade) or with friends (B- grade). }\end{array}$ \\
\hline Government & $\mathrm{C}$ & $\begin{array}{l}\text { There was clear evidence of leadership and commitment to providing physical activity opportunities for children } \\
\text { and youth, though policy is overly focused on girls and adolescents. There was only limited allocation of funds } \\
\text { and resources for implementation of policy. Only limited progress through the key stages of public policy- } \\
\text { making (policy agenda; policy formation; policy implementation; policy evaluation; decisions about the future) } \\
\text { had been demonstrated, with policy efforts stalling at implementation and evaluation }\end{array}$ \\
\hline Physical Fitness & INC & There are no nationally representative data on physical fitness in children and adolescents in Scotland. \\
\hline
\end{tabular}

demonstrating major limitations with Scottish health surveillance. Future child and adolescent health surveillance in Scotland should adopt best practice from other countries (e.g. Canada ${ }^{10}$ ), including objective measures of physical activity.

\section{References}

1. Reilly JJ, Dick S, McNeill G, Tremblay MS. Results from the Scottish report card on physical activity for children and youth. $J$ Phys Act Health. 2014;11(suppl 1):s93-s97. doi:10.1123/jpah.2014-0183

2. Reilly JJ, Johnstone A, McNeill G, Hughes AR. Results from the Scottish 2016 report card on physical activity for children and youth. J Phys Act Health. 2016;13(suppl 2):s251-s255. doi:10.1123/jpah. 2016-0325

3. Health Behaviour in School-Aged Children Scotland National Report 2014. (HBSC 2014).

4. McCrorie P, Mitchell R, Ellaway A. Comparison of two methods to assess physical activity prevalence in children. Br Med J Open. 2018; 8:e018369.
5. Scottish Health Survey (SHeS) 2016 Main Report. www.gov.Scot/ publications/2017/10/2970.

6. Basterfield L, Adamson AJ, Parkinson KN, Maute U, Li PX, Reilly JJ. Surveillance of physical activity in the UK is flawed: validation of the Health Survey for England physical activity questionnaire. Arch Dis Child. 2008;93:1054-1058. doi:10.1136/adc.2007.135905

7. Report of the World Health Organisation Commission on Ending Childhood Obesity. Geneva, Switzerland: WHO; 2016.

8. Farooq MA, Parkinson KN, Adamson AJ, et al. Timing of the decline in physical activity in childhood and adolescence: Gateshead Millennium Cohort Study. Br J Sports Med. 2018;52(15):1002-1006. doi:10.1136/bjsports-2016-096933

9. Janssen X, Mann K, Basterfield L, et al. Development of sedentary behavior across childhood and adolescence: longitudinal analysis of the Gateshead Millennium Study. Int J Behav Nutr Phys Act. 2016; 13:88. doi:10.1186/s12966-016-0413-7

10. Barnes JD, Cameron C, Carson V, et al. Results from Canada's 2016 ParticipACTION Report Card on Physical Activity for Children and Youth. J Phys Act Health. 2016;13(suppl 2):s110-s116. doi:10.1123/ jpah.2016-0300 